\title{
РАСПРОСТРАНЕНИЕ ИДЕЙ МАРКСИЗМА ГРАЖДАНАМИ КИТАЯ, ПРОЖИВАЮЩИМИ НА ТЕРРИТОРИИ РОССИИ'
}

\section{THE SPREAD OF THE IDEAS OF MARXISM BY CHINESE CITIZENS RESIDING ON THE TERRITORY OF RUSSIA}

\author{
He Bing \\ Zhang Wei
}

Summary: This article presents the results of a study aimed at establishing the main causes and ways of spreading the ideas of Marxism among Chinese citizens by their compatriots living in Russia. In the course of the study, it was found that the main reasons for the translation of Marxist ideas by Chinese citizens among their compatriots are the unfavorable socio-economic conditions that developed in the early 1860 s. As active participants in the 0ctober revolution that took place on the territory of Russia, Chinese citizens gained experience in building the first socialist country, which they tried to pass on to their compatriots in order to find the most optimal ways to gain independence of the country and its way out of the current critical situation.

Keywords: Chinese citizens, ideas of Marxism, the Soviet state, reasons, goals.

Хэ Бин

Дочент, Хэйхэский университет, провинция Хэйлунизян, город Хэйхэ, Китай hebing-123@163.com

Чжан Вэй

Доцент, Хэйхэский университет, провинция Хэйлунцзян, город Хэйхэ, Китай hhxytzb@163.com

Аннотация: В настоящей статье представлены результаты исследования, целью которого стало установления основных причин и путей распространения идей марксизма среди граждан Китая их соотечественниками, проживающими на территории России. В ходе исследования было установлено, что в качестве основных причин трансляции идей марксизма гражданами Китая среди своих соотечественников, выступают неблагоприятные социально-экономические условия, сложившиеся в начале 1860-х годов. Будучи активными участниками произошедшей на территории России Октябрьской революции, граждане Китая приобрели опыт построения первой социалистической страны, который пытались передать своим соотечественникам с целью поиска наиболее оптимальных путей приобретения независимости страны и её выхода из сложившегося критического положения.

Ключевые слова: граждане Китая, идеи марксизма, Советское государство, причины, цели.

\section{Введение}

$\mathrm{H}$ еобходимость рассмотрение проблемы настоящего исследования, обусловлена желанием выявить основные причины распространения идеи марксизма, как философского, экономического и политического учения, основанного К. Марксом и Ф. Энгельсом в начале 1860-х годов среди граждан Китая, проживающих на территории России. Обращаясь к сложившимся на данный исторический период социально-экономическим условиям Китая, следует отметить, что именно в это время произошло массовое обанкрочивание китайских фермеров, что вынудило большинство из них пересечь границы России с целью улучшить свои финансовые поступления за счет освоения новых территорий. Подобная эмиграция привела к резкому увеличению количества граждан Китая на территории России и образованию этнических обществ - маргинальных групп, осуществляющих свою деятельность вдали от родины.

В желании реализовать свой гражданский потенциал

граждане Китая активно осуществляли деятельность, направленную на пропаганду ценности марксистской теории среди соотечественников, видя в них новую мысль и знания, способные улучшить сложившиеся на указанный период времени социально-экономическое положение Китая. Граждане Китая не ограничились участием в Октябрьской революции, а прямо или косвенно (создание газет, школ, профсоюзов) распространили идеи марксизма в Китае [1]. Остановимся более подробно на причинах и последствиях вышесказанного.

Первоначально, обратим внимание на так называемые прямые причины (предпосылки), сподвигнувшие граждан Китая, проживающих на территории России, к распространению идей марксизма. В качестве первой из них мы видим приобретение опыта китайский граждан в участии Октябрьской революции в России основание которой составляла названная теория. Последствия Октябрьской революции отразились в позитивных изменениях в социальной и экономической политике молодого государства, что, собственно, укрепило доверие граж- 
дан Китая в эффективности основных положений теории марксизма и подтолкнуло к их продвижению среди соотечественников.

\section{Хом исследования}

Обращаясь к ретроспективному анализу, следует отметить, что начиная с 1840 г. Китай постепенно превратился в полуколониальную и полуфеодальную страну, что обусловило поиск наиболее оптимальных путей приобретения независимости страны с целью выхода её из сложившегося критического положения. Крестьянская война против маньчжурской империи Цин и иностранных колонизаторов, получившие название «Тайпинское Небесное Царство», сильно подорвало традиционно сложившиеся государственное правление Китая, позволив тем самым капитальному империализму увидеть мощь китайского народа и отказаться от идеи разделения страны с целью её подчинения.

В качестве основного механизма своеобразной защиты от возможности воплощения указанной идеи выступала попытка трансформации артефактов китайского общества путем изучения передовых западных технологий, для противостояния вторжению капиталистического империализма в Китае. Однако в виду крайней степени коррумпированности китайской социальной системы названный механизм не привел к намеченной цели. Реформисты буржуазии надеялись развить капитализм в Китае через движение реформ сверху вниз для реализации институциональной цивилизации Китая. Однако из-за имеющихся в текущий момент времени ограничений в действиях императора, не обладающего реальной властью, план не достиг своего завершающего намеченного этапа и привело к прекращению, так называемой Кампании Восстановления всего за 103 дня.

Следующие Учанское восстание было организовано с целью свержения феодальной монархии с последующим основанием Китайской народной республики. Однако из-за «слабости» китайской буржуазии, власть стала принадлежать другим представителям общества, что в итоге привело вновь к полуколониальному и полуфеодальному обществу. Данное обстоятельство привело к пониманию необходимости внесения ряда изменений в направленность преобразований в рамках осуществляемой идеологии и организации нового культурного движения в идеологических кругах Китая.

Сложившиеся на рассматриваемый период времени социально-экономические и политические условия в стране, характеризуемые неким миксом признаков империализма, феодализма и бюрократического капитализма, обусловили необходимость продолжения поиска наиболее оптимальных путей реформирования государственной политики с целью выхода Китая из затяжного критического состояния.

Более детальный анализ сложившейся в конце XVIII в. в России и Китае были ситуаций, позволил установиться схожие черты. Осознанное понимание «желтыми рабами» (граждане Китая, проживающие на территории России) сказанного и проведение аналогий, привело к выводу о важности Октябрьской революции не только в России, но и необходимости подобных коренных изменений у себя на родине.

Облегчение жизни различным представителям национальных меньшинств, проживающих на территории России стало благодаря изданным Советским правительством «Декларации прав народов всех национальностей в России» и «Постановления Народных комиссаров государственной службы о трудящихся из-за рубежа», в которых утверждался равный статус всех этнических групп перед коренными жителями России. Таким образом, именно Советское правительство стало первым защищающим интересы граждан Китая, проживающих в пределах его границ [2].

Вместе со сказанным приходит понимание того, что Всесоюзная Коммунистическая партия и советский режим выступили в роли тех политических партий и режимов, которые действительно представляли широкие массы граждан, имеющие равные права и возможность контролировать власть, став настоящим «хозяином» страны.

Победа в Октябрьской революции рабочих, крестьян, солдат и др. продемонстрировала силу истинности идей марксизма и позволила понять, что «они могут жить подругому. Жить не так, как они привыкли, а жить в соответствии с принципами равенства и справедливости. Трудящиеся России взяли власть в свои руки и в этом подали пример для всего мира и для нас, китайцев» [3]. Таким образом, победа в Октябрьской революции выступила в качестве идеологического оружия ориентира, указывая путь необходимых преобразований в надежде привести Китая к устойчивому развитию, проявляемому во всех сферах жизнедеятельности человека. Сказанное выступило в качестве одной из причин начала распространения идей марксизма в Китае.

В качестве косвенной причины распространения идей марксизма гражданами Китая выступает понимание необходимости преобразований посредством своеобразного «переноса» личного опыта китайцев, полученных им в России, при котором немаловажную роль сыграло созданное Генеральное общество китайских рабочих.

По мнению, высказанному В.И. Лениным «<...> победивший пролетариат лишил капиталистов и организовал 
социалистическое производство в своей собственной стране, противопоставляя себя остальной капиталистический мир, и тем самым привлекая к воссоединению угнетенные классы других стран» [4]. Как крупнейшая соседняя с Россией держава Китай, граждане которой проживали на территории Советского государства, привлекла внимание Всесоюзную коммунистическую партию большевиков (далее - ВКП(б), которая разработана ряд мер направленных на воспитание граждан Китая в духе идей марксизма и коммунизма, путем передачи опыта Октябрьской революции. В целом, подобные меры позволили принять как непосредственное, так и опосредованное участие граждан России в китайской революции с целью достижения организации на территории Китая коммунистической партии и проведения социальной революции.

Для оказания помощи китайским учащимся, коммерсантам и рабочим в России в 1917 г. создаётся Генеральное общество китайских гражданин [5]. После Октябрьской революции в России количество членов названного общества постепенно увеличивалось, которые в последствии приняли активное участие в строительстве Советской власти. Данное общество позднее было переименовало на «Генеральное общество китай- ских рабочих в России», превратившись в организацию рабочих, возглавляемую российским пролетариатом. Общество учредило газеты, открыло партийные школы и курсы повышения квалификации, с целью достижения максимально возможного распространения марксизм среди китайских рабочих в России. С развертыванием пропагандистской работы ВКП(б), Советским правительством и Генеральным обществом китайских рабочих в России, политическое сознание китайцев, проживающих на территории Советского государства постепенно увеличивалось, что привело к расширению пропагандистских мероприятий, ориентированная на распространение идей марксизма в Китае.

\section{Зак^ючение}

Сохранение кровных уз граждан Китая, проживающих на территории России с родственниками, позволило транслировать идеи марксизма, передавая их «из уст в уста». Подобная «естественная» пропаганда позволила побудить местных крестьян войти в эмоциональный резонанс и послужила причиной трансляции идей марксизма на широкой территории Китая среди его жителей, включая самые отдалённые деревни, охватывая тем самым большую площадь государства.

\section{ЛИТЕРАТУРА}

1. 从喜权, 安全义, 张巍, 董雪. 旅俄华侨对马克思主义中国化影响的新思考 [J]. 黑河学院学报, 2019.

2. 中央研究院近代史研究所编. 中俄关系史料一般交涉民国九年 [M]. 台北: 精华印书馆股份有限公司, 1968.

3. 张福山, 周淑珍. 哈尔滨与红色之路 [M]. 哈尔滨: 黑龙江人民出版社, 2001.

4. 列宁选集（第 2 卷） [M]. 北京：人民出版社， 1995.

5. 张慧洁. 旅俄华侨与马克思立义的早期传播研究（1916-1922）［D］。武汉：华中师范大学， 2019. 